\title{
THE MISSION OF THE CHURCH IN DIALOGUE WITH NON-CHRISTIAN RELIGIONS
}

\author{
Irena AVSENIK NABERGOJ'
}

COBISS 1.01

\section{ABSTRACT \\ The Mission of the Church in Dialogue with Non-Christian Religions}

The article provides a brief overview of the milestones that have encouraged new approaches to the missionary activities of the Church throughout history. The main purpose is to determine how the Second Vatican Council responded to the process of globalization after the Second World War, what its understanding of inculturation was, and what new pathways for evangelization were sought in the missionary activities of the Church. The methodological principle is the comparative analysis of documents on the foundations, goals and means of pursuing the mission in a spirit of dialogue, enabling the recognition of good contributions from non-Christian religions. The article also includes more recent theological discourse on new challenges in attitudes to the mission.

KEY WORDS: the mission of the Church, milestones of the missions throughout history, renewal in relation to tradition, common core of all religions, dialogue

\section{IZVLEČEK}

\section{Misijonsko poslanstvo Cerkve v dialogu z nekrščanskimi verstvi}

Članek daje kratek pregled mejnikov, ki so spodbudili nove pristope v misijonski dejavnosti Cerkve skozi zgodovino. Poglavitni namen je ugotoviti, kako se je Drugi vatikanski koncil odzval na proces globalizacije po drugi svetovni vojni, kakšno je bilo njegovo razumevanje inkulturacije in kakšno iskanje novih poti evangelizacije v misijonski dejavnosti Cerkve. Metodološko načelo je primerjalna analiza dokumentov o utemeljevanju, cilju in načinu izvajanja misijona v duhu dialoga, ki omogoča prepoznavanje dobrih vsebin nekrščanskih verstev. Članek vključuje tudi novejši teološki diskurz o novih izzivih v pristopih k misijonu.

KLJUČNE BESEDE: misijonsko poslanstvo Cerkve, mejniki misijona skozi zgodovino, prenova v razmerju do tradicije, skupno jedro vseh religij, dialog

PhD in Literary Sciences and Theology, Full Professor and Research Counsellor, ZRC SAZU, Institute for Cultural History, Novi trg 2, SI-1000 Ljubljana; University of Ljubljana, Faculty of Theology, Institute for the Bible, Judaism and Early Christianity; University of Nova Gorica, Faculty of Humanities; irena.avsenik-nabergoj@zrc-sazu.si 


\section{INTRODUCTION}

In my article "From Poeticization of the Mission in the Old Testament to Completion of the Mission in the New Testament", published in 2018 in the journal Bogoslovni vestnik / Theological Quarterly Ephemerides theologicae, I paid specific attention to the most important texts of the Old and New Testaments, which speak of national attitudes to God and the vocation of certain biblical individuals in the Old and New Testaments for missionary work. I especially highlighted the role of the Apostle Paul, who is considered the greatest missionary of the first Christian era. In his letters, he justifies the missionary nature of the Church stemming from the Bible. In this contribution, which is the continuation of the previous one, we are particularly interested in the biblical and theological reasoning of the mission itself and the attitude of the Catholic Church to non-Christian religions in the circulars of Pope Pius XI on the Catholic Missions (1926) and in the documents of the Second Vatican Council, in particular in the Statement on the relationship of the Church to non-Christian religions (Nostra Aetate, as a conciliar declaration adopted in 1965). Various church documents from the mid-19th century onwards and more recent specialist theological literature show that the views of the Catholic Church in the modern age have changed in their rationale and realization of the mission.

The Bible texts of the Old and New Testaments show a contrasting relationship between the widening and deepening vision of the prophets, who understood and proclaimed the Holy revelations with an openness to nations, and advocated a narrow, Land of Israel-oriented concept in choosing the Israelites as a special people among all others. In the New Testament, this contrast was so marked that there was a break between Judaism and Christianity. This led to the realization that based on the teachings of Jesus and his examples, the Kingdom of God was intended for all nations. In the New Testament, the mission is based on faith in God, who through his Son, Jesus, acts in the world and mediates God's love among people. Likewise, missionaries should pass on blessed love and faith in the goodness of God for all humanity who, irrespective of religious diversity and cultural affiliation, all share the same, or similar, fundamental questions about the origin, meaning and purpose of human life.

The establishment of missionary activity in the biblical Book of Wisdom is emphasised by Brian Hearne, who believes that comprehensive understanding and realization of the mission is based on the example of the mission of Jesus, who loved people of all cultures and religions, and who notes: "A lot of thinking about mission and development, in both religious and secular, Catholic and Protestant groups, neglects this rootedness with the ensuing respect for other cultures - the cultures of today, not of yesteryear, for culture is a dynamic and changing thing, not a dead fossil" (Hearne 1993: 94). On the mission, William R. Burrows, emphasizes, above all, the importance of dialogue, which is an essential dimension of the Christian mission, but is not the conversion of people of other religions. Conversion may happen, but 
initially through dialogue, as follows: "Christian mission, in a reciprocal dialogue context, is not primarily a matter of converting people from other traditions to belonging to Christian institutions, but of embodying the Spirit of Jesus. Conversions may (and probably will) develop within the dialogue process" (Burrows 1997: 127-128).

From Paul onwards, some missionaries followed the principle of dialogue with followers of other religions, and as a generally accepted rule, this principle came to the fore only during the transformed understanding of the mission in the 20th century, when a more holistic understanding of the Church's missionary nature came about upon its return to the sources of the Bible. In the first half of the 19th century, a highly noted circular on Catholic missions was issued by Pope Pius XI on 28 February 1926 entitled Rerum Ecclesiae (On Matters of the Church). The circular greatly accelerated the development of the mission between the two world wars. Like the First war, the Second World War greatly restricted missionary activity. The horrors of war that so shook communities and individuals around the world left significant physical and moral devastation behind them. Many unresolved issues accumulated for the missionary activities of the Catholic Church, along with concern for the future fate of the Church around the world. The greatest problem was the lack of educational institutions in missionary countries, which in turn meant a lack of domestic missioners and missionaries in those places; the issue of how to overcome the legacy of colonialism was especially challenging for foreign missionaries.'

These circumstances explain why, on 11 October 1962, Pope John XXIII convened the Second Ecumenical Council of the Vatican; or Second Vatican Council. At this assembly, the bishops of all the churches discussed the Church's issues in their entirety; its science or doctrine, its liturgical practice, and the fundamental religious truths. ${ }^{2}$ The interpretation of the missionary nature of the Church at the Second Vatican Church Assembly is based on the Bible and on the history of the Church: "From that history, one learns what the Church understands her mission to be; it is a story with many stages and shows an evolution in the thought and practice of mission in and to the world" (George 2008: 287).

1 After World War I affected missionary activities, on 20 November 1919 Pope Benedict XV, who advocated the de-Europization of Catholic missions, invited Catholic missionaries from around the world to support missions and develop local missionaries. This was followed by Pope Pius XI, who personally ordained bishops from Asia, Africa and Latin America every year, so that at his death, 240 dioceses and administrations were in the hands of domestic bishops.

2 The assembly is supposed to extend to the entire inhabited world, as indicated by the word "ecumenical", which is of Greek origin meaning "inhabited". In the first centuries of Christianity, the Ecumenical Council represented the assembly of all Christian Churches, and after the split between East and West in 1054, opinions changed about which churches should be included to ensure the council remained ecumenical. Today, Catholics and Orthodox Christians, as well as some Protestants, recognize the authority of the first seven Ecumenical Councils; in the subsequent councils, there are differences in this respect. For a chronological overview of the conciliar see Strle 2004: 18-20; Flinn 2007: 193-197. 


\section{HISTORICAL MILESTONES OF THE CHURCH'S MISSIONARY ACTIVITY UP TO THE SECOND VATICAN COUNCIL}

For a holistic understanding of the role of the mission in the Church, one must always take into account the authority that Jesus gave to his apostles in Galilee after his resurrection: "Go therefore and make disciples of all nations, baptizing them in the name of the Father and of the Son and of the Holy Spirit" (Matt 28:19). ${ }^{3}$ The apostles of Jesus, therefore, are "sent" (lat. mittere) by this universal authority.

On this basis, the singular concept of the "mission" means that the entire activity of the Church is about the continuation of the Kingdom of God on Earth, and the plural form has a narrower meaning and refers to forms of evangelization - inviting people to a relationship with God through Jesus Christ, usually with a missionary some distance from their homeland, and often in a context that is alien to their social and cultural background. The Apostle Paul is often considered to be the first true missionary and the most versatile interpreter of Jesus' authority, although by the beginning of his work, the Church had already expanded geographically. $\mathrm{He}$ and other apostles performed missionary activities in the biblical lands and in the surrounding regions of the Roman Empire, while Emperor Constantine (272-337) allowed the Christian Church to freely undertake missionary activity throughout the Roman Empire. In the period from the 6th to the 9th century, several great missionaries spread Christianity among the Germanic (St Boniface) and Slavic peoples (Sts Cyril and Methodius), but in the 8th century, the Church's missionary activity was halted by the expansion of Islam.

The split of the former Roman Empire into the east and the west in 1054 marked the beginning of the weakening of the eastern empire due to the spread of Islam, which led to the Crusades, the rise of the caliphates and eventually the Turkish empire. The split between the eastern and western churches led the Catholic Church to assert its missionary theology and practice in terms of dialogue in relation to non-Catholic Christian denominations and non-Christian religions. Cultural differences were increasingly reflected during the development between the eastern and western parts of the former Roman Empire that also significantly influenced economic and political relations. In the 16th century, the advent of Protestantism caused a similar split in the Western Church. The Council of Trent, held in Trident (nowadays Trento, Italy) in 1545-1563, was the response to the challenge of Protestantism, which at the same time encouraged intensified missionary activity by the newly founded Jesuits (in 1540). Some great missionaries emerged from this order, paving the way towards the Far East. In 1552, Francis Xavier arrived in India along with 50 brothers. From 1580, Mateo Ricci spread the Jesuit order in China; during that time, the mission was also begun in Japan, and, in 1549, the Jesuits reached the Portuguese colony of Brazil. The Jesuits introduced a new approach to the mission by adapting to the

The outline that follows is based on the article "Missions" (Flinn 2007: 455-459). 
original culture of new missionary countries. The published condemnation by Pope Clement XI, Ex illa die (19 March 1715), halted the mission in the region by banning Jesuit missionary activity in China.

In western Europe, from the 16th century onwards, we witness the accelerated development of science, the great discovery of new worlds, and the spread of global colonial empires such as Spain, Portugal and France. During that time, through cooperation between the missionaries and the colonial authorities, the spirit of the mission departed from the spirit of Jesus' authority to the apostles. The darkest form of this cooperation was the introduction of the Inquisition. The leadership of the Church responded to the new challenges through the increased centralization of the Church's missionary work around the world. Pope Gregor XV founded the Central Vatican Office for Missions in 1622, called the Congregation for Propagation of the Faith. After the Second Vatican Council in 1969, this institution was renamed the Congregation for the Evangelization of Peoples. The centralization of the mission resulted in the missionaries being bound to the western form of the Catholic Church, such that the Church in the new missionary countries, for example in Africa and Asia, was considered a foreign institution, which in some cases led to resistance from the local authorities.

At the end of the 18th century, the expansion of the mission ceased due to a ban on the activities of the Jesuit Order and by the French Revolution. The rapid expansion of the British colonial empire began at that time, which supported an intensive mission of Protestant confessions, as with the Methodists and Baptists. At the First Vatican Council, held in 1870 at the Vatican itself, the papal primacy (championship) was confirmed and the rule of papal infallibility was established. This caused a degree of disarray, since some did not agree with the infallibility of the Pope. The Old Catholic Church was formed, which does not recognize this provision. The Council Fathers also established the definition of Catholic faith within the Dei Filius doctrinal constitution, which deals with the fundamental question of reciprocity between faith and reason. During this period missionary activity was accelerated by the large orders. Competition between Protestant and Catholic missions in the 20th century encouraged efforts to collaborate in an ecumenical spirit. One of the fruits of the ecumenical approach to missions was a return to the sources of the Bible in substantiating and justifying the mission's purpose. On the Protestant, as well as on the Catholic side, the specialised subject of "missionology" was introduced at theological schools during the 19th and 20th centuries.

After the Second World War, Church missionary activity found itself faced with the significant challenge of liberating large nations from colonial rule. The United Nations was founded in 1946, India gained independence in 1947, and the communist People's Republic of China was established in 1949. A powerful "Liberation Theology" movement began in South America. New challenges following the Second World War gave rise to Pope John XXIII's (1958-1963) idea of convening the Second Vatican Council. The Pope opened it on October 11, 1962, and, after his death, it was 
continued and closed by Pope Paul VI (1963-1978). ${ }^{4}$ In his brief outline of the importance of the Second Vatican Council, Frank K. Flinn highlights the essence of the epochal novelties of this Council:

Vatican Council II served as a watershed even in changing perspectives on the Church's missionary life. The various documents from the council emphasized the primacy of God in the church's mission. God sends the Son into the world followed by the activity of the Holy Spirit. The church, as a community of the people in relation to God, participates in God's activity in the world. Mission is the work of the church, that is, all God's people.

This new approach to mission would have the church do mission as the "re-presentation" of Christ to the world. It also calls for a revised understanding of those people who have adhered to another faith either by birth or adult choice. The council saw it important to affirm the existence of other religions and the good that they represent in Nostra Aetate, the Declaration on the Relation of the Church to Non-Christian Religions. In the future, dialogue with other religions became a part of the Church's mission. (Flinn 2007: 458)

The great emphasis of the Second Vatican Council was on the relationship of the Church to other religions and in promoting dialogue to also include greater openness to the idea of inculturation in terms of adapting to the cultures of missionary countries, and, above all, to the fulfilment of the biblical requirement for liberating the poor, the oppressed and the suffering.

To fully understand the changes brought by the Second Vatican Council, one must turn to the major official documents of the Catholic Church, which define the rationale, purpose and nature of the mission. Among these documents, attention is directed to the Catholic understanding of the mission in two documents: the encyclicals of Pope Pius XI on the advancement of sacred missions, Rerum Ecclesiae (dated 28 February 1926), and the statement by the Second Vatican Ecclesiastical Council on the relationship of the Church to non-Christian religions, Nostra Aetate (dated 28 October 1965).

We shall provide a brief overview of how the Rerum Ecclesiae (On matters of the Church) circular, which the "missionary" Pope Pius XI issued on 28 February 1926, helped to explain the concept of the missions as it prevailed in the first half of the

4 The Council or universal church assembly is the "meeting of the bishops of the Catholic Church from around the world" who want to "express (and develop) a living (based on the scriptures) the traditional and religious conscience of the entire Church" (see Strle 2004: 15). In it, "the entire episcopate under the Pope's presidency is consulted and takes decisions in a collegial act" (ibid.).

5 The encyclical with commentary was published in Slovene as a manuscript at Christmas 1943 in Ljubljana. The manuscript was issued by the Missionary Youth Association with the permission of the Directorate of the Missionary Society. 
20th century. The encyclical of 34 articles contains instructions for missionary work in Christian lands and instructions for work in missionary countries. In the introduction, the Pope clearly indicates that the term "mission" is understood as a way of spreading the Christian Gospel to remote lands and places where the gospel has not yet penetrated. All emphasis is placed on establishing the Catholic Church in places where it has not reached. However, since the Church cannot be established without native believers, it is necessary to consolidate it in these countries and become rooted in order to obtain "homeland" rights in the new missionary country.

In the third article of the encyclical, Pope Pius XI reveals his vision of the missionary activity in the Catholic Church. It not only emphasizes missionary work in non-Christian lands, bringing their abilities in various fields and in spreading the goodness of the Christian faith, but also their role in educating believers to take up missionary work. In addition, he mentions the lack of missionaries resulting from the First World War, which severely curbed the Church's missionary activity. In the second part of the encyclical, he addresses believers and missionaries in the missionary countries, and encourages priests (missionaries) to become local. In this way, the most important goal of the mission could be achieved, namely that the Catholic Church in the missionary country not only becomes established, but also becomes consolidated. This aim is based by reference to the apostolic age of the first Christian community. In his words, the apostles and their immediate heirs always spread the gospel such that some believers, in some places, convert, followed immediately by one of the new communities coming to the fore. As mentioned in the encyclical, concern for the education of local priests (missionaries) includes establishing missionary seminaries. Missionaries should also be of valuable help to catechumen being raised by the missionaries in special schools.

The encyclical recommends establishing hospitals, pharmacies, schools and various institutions, such as trade associations; establishing universities; an emphasis on Catholic intellectuals; care for students from missionary countries studying in Europe and America; preparing native Catholic teachers to assume responsible service in a missionary country; collaboration between scientists in Christian countries with scientists in missionary countries; studying all fields of the culture in specific missionary countries, and infusing those cultures with Christian thought; creating native Christian art, etc. ${ }^{6}$

6 This line of thought matches the term "inculturation", which guides more and more missionaries these days. For the meaning of the term "inculturation" see Flinn 2007: 362. 


\section{THE MISSION IN DOCUMENTS OF THE SECOND VATICAN COUNCIL: A RETURN TO SOURCES AND INTERFAITH DIALOGUE}

At the time of the Second Vatican Ecumenical Council, the composition of the bishops' assembly was quite different from the current arrangements, especially regarding the so-called "mission territories". Around 2,090 bishops came from the Americas and Europe, 408 from Asia, 351 from Africa, and 74 from Oceania. The majority of bishops who came from missionary zones were Europeans and belonged to missionary institutions. It was the bishops from the missionary regions, in particular, who brought with them missionary issues and experiences that called for a return to biblical sources. The Second Vatican Church Assembly brought the most innovation in its emphasis on the need to return to the sources, and opening the possibility of a better interfaith dialogue.

In relation to other religions and to the mission, the assembly developed conciliar documents in Latin, which are presented in the chronological order of the bishops and theology as follows: Constitution on Sacred Liturgy (Sacrosanctum concilium), adopted and confirmed on 4 December 1963; Declaration on the Relationship of the Church to non-Christian religions (Nostra aetate), adopted and approved on 28 October 1965; Dogmatic Constitution on the Church (Lumen gentium), adopted and approved on 18 November 1965; Decree on Mission Activity of the Church (Ad gentes), adopted and approved on 7 December 1965; and the Pastoral Constitution on the Church in the Modern World (Gaudium et spes), adopted and approved on 7 December $1965 .^{7}$

\section{Constitution on Sacred Liturgy, Sacrosanctum concilium (1963)}

The primary innovation of the Second Vatican Council is that in its interpretation of the nature and purpose of the liturgy it not only addresses Christian believers, but all humankind. At the end of the second article, and on the basis of biblical sources, the constitution highlights the task of the Catholic Church to proclaim Christ to those who are outside the Church. The Church should "lift up a banner for the nations" (Isa 11:12), "under which the scattered children of God are gathered" (John 11:52), "that there will be one herd and one shepherd" (John 11:52). The 5th article of the first chapter of the constitution describes Paul's proclamation of the will of God "who desires everyone to be saved and to come to the knowledge of the truth" (1 Tim 2:4). In the 9th article, the constitution highlights the mission of the Church to prepare people of all nations for worship of the liturgy, and states Paul's dilemma: "But how are they to call on one in whom they have not believed? And how are they to believe in

7 For more on the course and the meaning of the Second Vatican Church Assembly, see Flannery 1992; Strle (ed.) 2004, Lamb, Levering (ed.) 2008; Marchetto 2010; Faggioli 2012 etc. In Slovene, the most comprehensive description of the Second Vatican Council can be found in Strle (ed.) 2004. 
one of whom they have never heard? And how are they to hear without someone to proclaim him? And how are they to proclaim him unless they are sent?" (Rom 10:1415). In the second paragraph of its 9th article, the answer is provided: "Therefore the Church announces the good tidings of salvation to those who do not believe, so that all men may know the true God and Jesus Christ whom He has sent and may be converted from their ways, doing penance" (e.g. John 17,3; Luke 2:47; Acts 2:38).

Gerald O'Collins devotes special attention to those elements of the constitution that cover the proclamation of the gospel to all humanity, and states: "Right from the first important text promulgated by the Council, we can see how the salvation of all humanity stood high in the spiritual imagination and agenda of the bishops and their advisors at Vatican II" (2013: 68). The emphasis on the salvation of all mankind does not mean a break with the previous history of the Church - on the contrary. In the constitution, the Church Fathers showed that "that the council be interpreted in continuity with the great tradition of the Church, including the teachings of earlier councils" (Cessario 2008: 130).

\section{Dogmatic Constitution on the Church, Lumen gentium (1964)}

Some commentators of this constitution described it as "revolutionary" in its presentation of the nature, mission and structure of the Church. A deeper look at its sources reveals that in reality the novelties stem from a deeper and broader understanding of the primary sources of Christianity, as Dulles finds: "Any aggiornamento that it accomplished was intrinsically connected with the principle of ressourcement" (Dulles 2008: 26). The constitution in the introductory article frames the Church on the basis of biblical and patristic statements.

Article 17 begins with the declaration in the Gospel of John that Jesus sent the apostles, as the Father sent the Son (cf. John 20:21), and Jesus' authorization of the apostles to announce to gospel to the all (Matt 28:18-20). An important novelty of the constitution is its definition of the attitude of missionaries of the Catholic Church to members of non-Christian religions. In the rituals and cultures of various non-Christian nations, the church should accept all goodness from the heart and spirit of the people. With the vision of the prophet Malachi for spreading the name of God "among nations" $(1,11)$, the Church shall also strive for the whole world to worship the Creator and the Father of Universe. In-depth descriptions of the basics of Christian faith and the life and activities of the Church in relation to other religions contained in the constitution of Lumen gentium are based on the biblical faith in God, which, through its creative work, invigorates, enlightens and consecrates all things and all people.

The Constitution stems from an important theological premise that God the Creator gives all people a voice of conscience and longing for good; therefore a person finds their way on their life path by different and various means. Christ's divine presence and grace are intended to inspire all people with the desire for unity. 


\section{Declaration on the Relationship of the Church to non-Christian religions, Nostra aetate (1965)}

On 7 December 1965, the Council Fathers adopted and confirmed the declaration on the missionary activity of the Church entitled Nostra aetate. This document laid the foundations for seeking the common core values and truths of all religions and for the development of interfaith dialogue, which remains a universal endorsement today. This is a shorter document of 5 articles; here we cite only the first paragraph of the first article:

In this age of ours, when men are drawing more closely together and the bonds of friendship between different peoples are being strengthened, the Church examines with greater care the relation which she has to non-Christian religions. Ever aware of her duty to foster unity and charity among individuals, and even among nations, she reflects at the outset on what men have in common and what tends to promote fellowship among them. (Flannery 1992: 738) ${ }^{8}$

In the light of these and other fundamental questions raised by people across the world, the statement in Article 2 positively assesses the Church's stance towards Hinduism and Buddhism. Of Hinduism it writes: "In Hinduism men explore the divine mystery and express it both in the limitless richness of myth and the precisely defined insights of philosophy. They seek release from the trials of present life by ascetical practices, profound meditation and recourse to God in confidence and love" (Flannery 1992: 739). It also gives a positive assessment of Buddhism: "Buddhism in its various forms testifies to the essential inadequacy of this changing world. It proposes a way of life by which men can, with confidence and trust, achieve a state of perfect liberation and reach supreme illumination either through their own efforts or by the help of divine help ..." (Flannery 1992: 739). The positive acceptance of non-Christian religions is dictated by the statement of principle in the second paragraph of Article 2: "The Catholic Church rejects nothing of what is true and holy in these religions ..." (Flannery 1992: 739).

In its emphasis on the need for brotherhood between all people (Article 5) the Nostra Aetate declaration devotes more attention to Hindu and Buddhist devotees than to Muslims (Article 3), and pays particular attention to the Jews (Article 4). As it notes, Christianity is most closely connected with Judaism, the unique role of the Jews as God's chosen people, and His special commitment to them, as Israel was

8 The Nostra Aetate declaration takes humanity as a single communion, which has the same origin and purpose for God. The text of the declaration is reminiscent of Wisd. of Sol. 8:1; Acts 14:16-17; 17:26; Rom 2:5-11; 1 Tim 2:4; Rev 21:23-24 (cf. second paragraph of the first article), taken as a return to the biblical basis. In the third paragraph, we find that the unity of all humanity determines the most primordial/original issues that are the same for all individuals and all nations at all times. These are questions about the meaning and purpose of human life, the nature of suffering, etc. 
chosen, by way of the "God of Israel" revelation, to pass on to other nations "a way of understanding other religions in their accounts of a transcendent eternal being and the different visions of human release from suffering and evil" (Kennedy 2008: 405).

\section{Decree on the Mission Activity of the Church, Ad gentes (1965)}

The introductory article of this document begins with the declaration that God sent the Church to the nations to be the universal sacrament of salvation. As the text emphasizes, the Council wishes to set out the principles of missionary activity as the intention to spread the Kingdom of Christ. The decree first describes the trinitarian foundations of the Mission.

The justification and foundation of the Mission's trinitarian principle relies on classic biblical texts that tell of God's plan of salvation, which is for all people: John 11:52; Acts 4:12; 2 Cor 5:19; 1 Tim 2:4. As pointed out, Jesus' mission represents a call to the missionary activity of the Church: "What the Lord preached that one time, or what was wrought in Him for the saving of the human race, must be spread abroad and published to the ends of the earth (Acts 1:8), beginning from Jerusalem (cf. Luke 24:27), so that what He accomplished at that one time for the salvation of all, may in the course of time come to achieve its effect in all" (Flannery 1992: 815). In the first chapter we also find a clear indication of the word "mission" as understood by the Second Vatican Church assembly:

\footnotetext{
"Missions" is the term usually given to those particular undertakings by which the heralds of the Gospel, sent out by the Church and going forth into the whole world, carry out the task of preaching the Gospel and planting the Church among peoples or groups who do not yet believe in Christ. These undertakings are brought to completion by missionary activity and are mostly exercised in certain territories recognized by the Holy See. The proper purpose of this missionary activity is evangelization, and the planting of the Church among those peoples and groups where it has not yet taken root. (Flannery 1992: 817)
}

The second chapter of the decree mainly highlights the task of carrying out the mission, meaning testimony of life, conversion. The biblical basis for understanding conversion is not foremost for people transitioning from one religion to another, but it is the conversion of the heart according to God's will, which, according to the prophets, is universal, and therefore directly or indirectly includes all people of the world.

The mission pays attention to the form of Christian communion (Article 15), the training of local priests (Article 16), the training of catechists (Article 17) and a fostering of normal life (Article 18). Chapter 3 is dedicated to the mission work of the regional churches, Chapter 4, training of the missionaries, Chapter 5 to the regulation of mission activity, and Chapter 6 to the duty of the entire Catholic Church to implement the mission. 
The purpose of the Second Vatican Council was not to establish a new basis for the mission, but to deepen understanding of the mission. In this, the universal church assembly proceeded from the belief of the uniqueness and universality of Jesus Christ, which brings complete salvation to all people.

\section{Pastoral Constitution on the Church in the Modern World, Gaudium et spes (1965)}

The basic content of this document is clearly expressed in the introductory paragraph to the forward:

The joy and hope, the grief and anguish of the men of our time, especially of those who are poor or afflicted in any way, are the joy and hope, the grief and anguish of the followers of Christ as well. Nothing that is genuinely human fails to find an echo in their hearts. For theirs is a community composed of men, of men who, united in Christ and guided by the Holy Spirit, press onwards towards the kingdom of the Father and are bearers of a message of salvation intended for all men. That is why Christians cherish a feeling of deep solidarity with the human race and its history. (Flannery 2008: 903-904)

Starting from the conclusion of the first biblical account on creation (Gen 1:26; cf. Wisd. of Sol. 2:23; Sir 17:3-10), the constitution elevates the biblical teachings of human godliness and its ability to know and love their Creator (Article 12, paragraph 3). Based on Paul's well-known explanation of conscience bearing witness, which is written in the hearts of men in Romans 2,14-16, Article 16 proclaims the dignity of man's conscience. As Article 16 states, conscience is about human dignity and the possibility of personal connection with God. Human godliness should be reflected in the fact that everyone poses the same fundamental questions about the origin, meaning and purpose of life (Articles 3, 4, 10, 21). They also receive the gift of faith in the Holy Spirit (Article 15). According to text in Article 38, Christ, who rose from the dead in Christianity, acts in the hearts of human beings.

Recognizing the interconnectedness of the whole of mankind "there is a growing awareness above all things and whose rights and duties are universal and inviolable" (Article 26, paragraph 2). Christ proclaims human freedom, rejects hatred and establishes the form of love (Article 41). From the beginning to end, the constitution approves and encourages dialogue and cooperation with people of all nations, religions and cultures. In particular, it emphasises interfaith dialogue in the quest for justice and peace (Articles 3, 4, 11, 28, 40, 44, 84, 92), thus justifying the Catholic understanding of the missionary nature of the Church. For example, in the first paragraph of Article 28, we read: "Those also have a claim on our respect and charity who think and act differently from us in social, political, and religious matters. In fact the more deeply we come to understand their ways of thinking through kindness 
and love, the more easily will we be able to enter into dialogue with them" (Flannery 2008: 928-929).

The religious foundation of the mission of the Church means that it is not tied to any economic, social or political system. Nevertheless, it must strive for respect of the law, personal rights and religious freedom. Evangelization can only achieve its goal when members of other religions and beliefs freely and absolutely choose to receive the gospel in recognition of its universal value.

\section{SIGNIFICANCE OF THE MISSION'S CONCEPTUAL DIMENSIONS OF INCULTURATION AND EVANGELIZATION IN RECENT THEOLOGICAL LITERATURE}

Following the Second Vatican Ecclesiastical Council, most debate about the documents of this church council focus on the question of whether they represent the restoration of the Church in unbroken continuity with the two-thousand-year-old tradition or, in contrast, break with tradition. At the centre of attention are the terms "inculturation" and "evangelization" and their reciprocity. We are interested in how questions about the mission are answered in recent studies. We established that the most important recent studies are derived from biblical sources and patristic explanations, and also take into account recent searches into anthropological argumentation of the Church's missionary nature. The in-depth writings of all Christian denominations are particularly and primarily interested in biblical sources to understand the mission. ${ }^{9}$ It is worth noting the maturing notion of "inculturation" from the official definition of this concept in the 1998 document of the International Theological Commission entitled "Faith and Inculturation". The notion of inculturation as set out in Article 11 of the first part of the document is interpreted as follows:

The process of inculturation may be defined as the Church's efforts to make the message of Christ penetrate a given sociocultural milieu, calling on the latter to grow according to all its particular values, as long as these are compatible with the Gospel. The term inculturation includes the notion of growth of the mutual enrichment of persons and groups, rendered possible by the encounter of the Gospel with a social milieu.

The essential emphasis of the council documents on the attitude of the Church to other religions is recalled in the study Christianity in India: From Beginnings to the Present (2008), written by missionary and historian Robert Eric Frykenberg. In his explanation,

9 On the basis of a comparative analysis of the texts of the Old and New Testaments that deal with understanding of the relationship of God to Israel and other nations, in his book, Mission in the Old Testament: Israel as a Light to the Nations (2000), Walter C. Kaiser Jr. concludes that not only does the Old Testament have texts that emphasize God's plan of salvation solely for the Israelites, but also poetic descriptions of God's kindness to all nations (see also Ocvirk 2006). 
the biblical concept of the mission's purpose reflects the purest aspects of the primeval religion, which is so "universal" that it restricts "no person, culture or religion" and is referred to as "the spark of eternity". As with the Council Fathers, for Frykenberg the most important biblical reasoning for the mission are the doctrines of Jesus, and by his examples that he did not come for the rich, but for the poor who are open to the realization of spiritual truths. ${ }^{10}$ Today, more and more missionaries choose to live among people of other faiths and to work without any intention of turning them into a Christian community.

Even in his influential book, Transforming Mission: Paradigm Shifts and Mission Theology (Bosch 1991, 2011), the Protestant biblical exegete David Bosch builds his views on the mission on biblical grounds, especially on the gospel of Luke, apostolic works and the writings of Paul. For me as well, the challenges of time require a more in-depth theological approach, based on biblical hermeneutics. As a basis, "the first and cardinal change in the paradigm took place with the coming of Jesus of Nazareth and with what followed" (Bosch 2011: 15).

In his article "New Models of Mission" (1993), Brian Hearne concludes his commitment to the mission's holistic lifestyle and dialogue approach by noting that in the modern globalized world, what man most misses is the dialogue on the fundamental issues of life. In his opinion, the third millennium will see dialogue between people of different cultures, religions and beliefs and will take place on this basis: "What is needed is communication among people about the values, problems, joys and sorrows, hopes and fears of their lives ... Could we say that mission is about simplicities like affection and friendship, but extending them beyond the limits of one's own country, language, culture and religion?" (Hearne 1993: 97). Several other authors of scientific contributions to the mission also consider this approach. ${ }^{11}$ In the Nostra Aetate declaration, Article 3 highlights "simple things" when it refers to the attitude towards Muslims: "Over the centuries many quarrels and dissensions have arisen between Christians and Muslims. The sacred Council now pleads with all to forget the past, and urges that a sincere effort be made to achieve mutual understanding; for the benefit of all men, let them together preserve and promote peace, liberty, social justice and moral values."

\section{CONCLUSION}

In the New Testament, an image of the Church emerged which was missionary by its very nature. The Mission, also by its very nature, is concerned with the entire community, and less concerned about the wishes and interests of individuals. At the same time, a missionary can only be such when authorised by the Church. Throughout

10 See also Craig Ott 2010.

11 Wonderly, Nida 1963; Burrows 1997; Ott 2001; Ma 2007; Ma 2009. 
its missionary history, and although the missionary nature of the Church had been inspired by missionary activity, the expansion of the mission created new tensions between the deepening spiritual understanding of missionary work and various forms of political interest connected with economic and cultural colonialism. Due to this fundamental tension, the universal leadership of the Church had to remain alert regarding the course of the missions. The most important task of the Ecumenical Councils from antiquity to the present time has been the self-understanding the nature of the Church, which at the same time signifies the self-understanding of the Church regarding its mission.

With the outbreak of World War I and the onset of globalization that overran the world, the Church leadership had to respond to the challenges of economic, political, educational and cultural cooperation among all nations. This challenge caught the attention of the Council Fathers at the Second Vatican Council, who sought clear and unambiguous sayings from primary sources of the Holy Scriptures and texts of the Church Fathers about the missionary nature of the Church as the universal communion of man. It was for those who craved for the same, or a similar, way to happiness and love, as well suffering from its limitations in the same or similar ways. Returning to the spiritual sources of the Bible, whose messages reach their peak through the commandment of a love for God and one's fellow man, allows the continuous purification of the hermeneutics of the mission, both at the institutional level and at the level of living the truth according to the God's design and a love for all people of the world.

The fundamental principle of the direction taken by the Second Vatican Council is a return to the sources, and a theology that means returning to the biblical hermeneutics that are integral to, and based on, the idea of one God as the beginning and the end of the entire human history. According to biblical thought, God calls on "nations" to know the universal plan of salvation, with Israel chosen for an intermediary missionary role in relation to the "nations". The New Testament places God at the very centre of understanding, calling all nations to salvation. The New Testament specifically highlights the universality of natural law (conscience) and the gospels of Jesus on reciprocity between the commandments of love of God and love for one's fellow man. If love for one's fellow man is a measure of the fulfilment of the commandment of a love of God, it is clear that this reciprocity is the basis for the Church's attitude towards those who are not members of Christian communities, since the Bible acknowledges the spiritual greatness of all people on earth. Jesus and Paul, the prophets of the Old Testament, considered as the first missionaries of the nations, placed conversion at the centre of their proclamations. They were aware that the divine call to convert was primarily for them - meaning, that it is regarded as the basic guide of missionaries at all times. Conversion, by its very nature, means the realization of a dialogue with people of all nations, cultures and religious beliefs, or customs. 


\section{REFERENCES}

Avsenik Nabergoj, Irena (2018). Od poetizacije poslanstva v Stari zavezi do polnosti misijona v Novi zavezi. Bogoslovni vestnik 78/3, 679-694.

Bosch, David J. (1991, 2011). Transforming Mission: Paradigm Shifts in Theology of Mission. Maryknoll, NY: Orbis Books (American Society of Missiology Series; 16).

Brock, Peggy (2005). Indigenous Peoples and Religious Change. Leiden, Boston: Brill (Studies in Christian Mission; 31).

Burrows, William R. (1997). Christian Mission and Interreligious Dialogue: Mutually Exclusive or Complementary? Buddhist-Christian Studies 17, 119-130.

Cessario, Romanus (2008). The Sacraments of the Church. Vatican II: Renewal Within Tradition (eds. Matthew L. Lamb, Matthew Levering). Oxford: Oxford University Press, 129-146.

Dulles, Avery Cardinal (2008). Nature, Mission, and Structure of the Church. Vatican II: Renewal Within Tradition (eds. Matthew L. Lamb, Matthew Levering). Oxford: Oxford University Press, 25-36.

Faggioli, Massimo (2012). Vatican II: The Battle for Meaning. New York, Mahwah, NJ: Paulist Press.

Flannery, Austin (ed., rev) (1992). Vatican Council II: The Conciliar and Post Conciliar Documents. Northport, NY: Costello Publishing Company (Vatican Collection; 1).

Flinn, Frank K. (2007). Encyclopedia of Catholicism. New York: Facts on File: "Missions", 455-459.

Flinn, Frank K. (2007). Encyclopedia of Catholicism. New York: Facts on File: "Councils, Ecumenical", 193-197.

Frykenberg, Robert Eric (2008). Christianity in India: From Beginnings to the Present. Oxford: Oxford University Press.

Fuchs, Martin, Linkenbach, Antje, Reinhard, Wolfgang (eds.) (2015). Individualisierung durch christliche Mission? Wiesbaden: Harrassowitz Verlag (Studien zur Außereuropäischen Christentumsgeschichte (Asien, Afrika, Lateinamerika); 24).

George, Francis Cardinal (2008). The Decree on the Church's Missionary Activity, Ad Gentes. Vatican II: Renewal Within Tradition (eds. Matthew L. Lamb, Matthew Levering). Oxford: Oxford University Press, 287-310.

Hardiman, David (ed.) (2006). Healing Bodies, Saving Souls: Medical Missions in Asia and Africa. Amsterdam, New York, NY: Editions Rodopi.

Hearne, Brian (1993). New Models of Mission. The Furrow 44/2, 91-98.

International Theological Commission (1988). Faith and Inculturation, http://www. vatican.va/roman_curia/congregations/cfaith/cti_documentscti1988fe.

Jackson, Pamela E. J. (2008). Theology of the Liturgy. Vatican II: Renewal Within Tradition (eds. Matthew L. Lamb, Matthew Levering). Oxford: Oxford University Press, 101-128.

Kaiser Jr., Walter C. (2000). Mission in the Old Testament: Israel as a Light to the Nations. Grand Rapids, Ml: Baker Books. 
Kennedy, Arthur (2008). The Declaration on the Relationship of the Curch to Non-Christian Religions, Nostra Aetate. Vatican II: Renewal Within Tradition (eds. Matthew L. Lamb, Matthew Levering). Oxford: Oxford University Press, 397-409. Lamb, Matthew L., Lewering, Matthew (2008). Vatican II: Renewal Within Tradition. Oxford: Oxford University Press.

La Soujeole, Benoît-Domnique (2008). The Universal Call to Holiness. Vatican II: Renewal Within Tradition (eds. Matthew L. Lamb, Matthew Levering). Oxford: Oxford University Press, 37-53.

Levering, Matthew (2008). Pastoral Perspectives on the Church in the Modern World. Vatican II: Renewal Within Tradition (eds. Matthew L. Lamb, Matthew Levering). Oxford: Oxford University Press, 165-183.

Ma, Julie (2009). Eschatology and Mission: Living the "Last Days" Today. Transformation 26/3, 186-198.

Ma, Wonsuk (2007). The Spirit of God in Creation: Lessons for Christian Mission. Transformation 24/3-4, 222-230.

Marchetto, Agostino (2010). The Second Vatican Ecumenical Council: A Counterpoint for the History of the Council. Chicago, IL: University of Scranton Press.

Martens, Elmer A. (2007). Impulses to Mission in Isaiah: An Intertextual Exploration. Bulletin for Biblical Research 17/2: 215-239.

Ocvirk, Drago (2006). Misijoni - povezovalci človeštva: Krščansko misijonstvo v univerzalizaciji človeštva. Ljubljana: Družina (Znanstvena knjižnica; 8).

O'Collins, Gerald (2013). The Second Vatican Council on Other Religions. Oxford: Oxford University Press.

Ott, Bernhard (2001). Mission and Theological Education. Transformation 18/2, 87-98.

Ott, Graig, Strauss, Stephen J., Tennent, Timothy C. (2010). Encountering Theology of Mission: Biblical Fondations, Historical Developments, and Contemporary Issues. Grand Rapids, MI: Baker Academic.

Pius XI., pope (1926). Rerum Ecclesiae = Encyclical of Pope Pius XI on Catholic Missions. Rome: Libreria Editrice. Vaticana, http://analytics.catholica.va/piwik/piwik. php?idsite=56"style="border:0"alt="'"/ $></ p>$.

Shorter, Aylward. 1992. Toward a Theology of Inculturation. Maryknoll, NY: Orbis Books.

Strle, Anton (ur.) (2004). Koncilski odloki: Konstitucije, odloki, izjave, poslanice 2. vatikanskega vesoljnega cerkvenega zbora (1962-1965), slovenski prevod s splošnim uvodom in posebnimi uvodi k posameznim dokumentom / [avtor: Oecumenicum concilium Vaticanum (2; 1962-1965; Rim); besedilo dokumentov, ki so v slovenskem prevodu prvič izšli v snopičih v letih 1964-1966, izpopolnil, napisal splošni uvod in uvode k posameznim koncilskim dokumentom Anton Strle]. Ljubljana: Družina.

Wonderly, William L., Nida, Eugene A. (1963). Linguistics and Christian Missions. Anthropological Linguistics 5/1, 104-144. 


\section{POVZETEK}

\section{MISIJONSKO POSLANSTVO CERKVE V DIALOGU Z NEKRŠČANSKIMI VERSTVI Irena AVSENIK NABERGOJ}

Članek skuša dognati, kako so zgodovinske okoliščine v obdobju dva tisoč let, predvsem pa od 19. stoletja, krepile ali zavirale misijonsko miselnost in dejavnost Cerkve. Posebna pozornost velja dokumentom Drugega vatikanskega koncila, ki je s spodbujanjem dialoga znotraj krščanskih cerkva in v razmerju do nekrščanskih verstev celostno združil pogled $v$ zgodovino, sedanje stanje in vizijo prihodnosti. Namen natančnejše analize dokumentov, ki opredeljujejo naravo Cerkve glede na njeno misijonsko poslanstvo, je uvid v kompleksnost dejavnikov, ki so pripomogli, da je Drugi vatikanski cerkveni zbor vse prejšnje koncile in cerkvene dokumente presegel s sintetičnim spajanjem vračanja k svetopisemskim virom, s pozornostjo na strahove in upe narodov v sedanjem globalizacijskem procesu in z vizijo prihodnosti, ki jo omogoča le volja po dialogu $v$ duhu solidarnosti z vsemi, ki priznavajo univerzalne duhovne razsežnosti človekovega bivanja in iščejo nove poti k premagovanju medsebojne odtujenosti.

V 20. stoletju je zaradi nacionalističnih spopadov med narodi, ki so povzročili prvo in drugo svetovno vojno, nastopila kriza. Kriza pa je obenem postala tudi nova priložnost za čistejše razumevanje misijona, kar pomeni vračanje k prvobitnim virom njegovega razumevanja in izvajanja. Takšen odziv lahko zasledimo v okrožnici »misijonskega« papeža Pija XI. iz leta 1926 (Rerum Ecclesiae). Po zastoju misijonske dejavnosti zaradi druge svetovne vojne se je v Katoliški cerkvi zgodil največji premik, ki je na globalni ravni zaznamoval ekumensko usmeritev $v$ odnosu med krščanskimi veroizpovedmi, $v$ odnosu do judov, islama, hinduizma in budizma, pa tudi širše v odnosu do narodov, kultur in religij sveta. Vse to je vplivalo na odločitev, da je težišče pričujočega članka odkrivanje bibličnih osnov razumevanja misijona $v$ naslednjih dokumentih: Dogmatični konstituciji o Cerkvi, Lumen gentium (1964), Izjavi o razmerju Cerkve do nekrščanskih verstev, Nostra aetate (1965), Odloku o misijonski dejavnosti Cerkve, Ad gentes (1965), in dokumentu o Pastoralni konstituciji o Cerkvi v sedanjem svetu, Gaudium et spes (1965). Novosti Drugega vatikanskega koncila presojamo s pregledom novejše teološke literature o misijonu znotraj Katoliške cerkve in v protestantskih konfesijah, ki je vse bolj ekumenska. 